\title{
A Five-Level Inverter Topology with Single-DC Supply by Cascading a Flying Capacitor Inverter and an H-Bridge
}

\author{
P. Roshankumar, Student Member, IEEE, P. P. Rajeevan, K. Mathew, Student Member, IEEE, \\ K. Gopakumar, Fellow, IEEE, Jose I. Leon, Member, IEEE, and Leopoldo G. Franquelo, Fellow, IEEE
}

\begin{abstract}
In this paper, a new three-phase, five-level inverter topology with a single-dc source is presented. The proposed topology is obtained by cascading a three-level flying capacitor inverter with a flying $\mathrm{H}$-bridge power cell in each phase. This topology has redundant switching states for generating different pole voltages. By selecting appropriate switching states, the capacitor voltages can be balanced instantaneously (as compared to the fundamental) in any direction of the current, irrespective of the load power factor. Another important feature of this topology is that if any H-bridge fails, it can be bypassed and the configuration can still operate as a three-level inverter at its full power rating. This feature improves the reliability of the circuit. A 3-kW induction motor is run with the proposed topology for the full modulation range. The effectiveness of the capacitor balancing algorithm is tested for the full range of speed and during the sudden acceleration of the motor.
\end{abstract}

Index Terms-Flying capacitor (FC), H-bridge, induction motor drive, multilevel inverter.

\section{INTRODUCTION}

$\mathbf{M}$ ULTILEVEL inverters have changed the face of medium- and high-voltage drives [1], [2]. The most popular topologies of multilevel converters are the neutralpoint-clamped inverter (NPC) [3], the flyin capacitor inverter (FC) [4], and the cascaded H-bridge (CHB) inverter [5]. Each one of these inverters has its own merits and demerits [1]. In the NPC inverter [3], multiple dc sources are generated by splitting a single-dc bus voltage using capacitor banks. This configuratio has large number of clamping diodes and presents the problem of dc bus capacitor unbalance especially with high number of voltage levels [6], [7]. An interesting work for balancing capacitors in NPC inverter that can be operated in limited modulation range has been presented in [8]. A pulse-width modulation (PWM) control scheme to balance the dc link capacitor voltages of the NPC inverter, connected in cascade with a two-level inverter to realize a fi e level inverter structure for an open-end winding induction motor, is proposed in [9].

The concept of FC inverter was introduced firs in 1992 [4]. In this configuration multiple capacitors of different voltage magnitudes are used to generate multiple voltage levels. The advantages include modularity, lack of clamping diodes, lack of problems like unbalance in the split dc -link capacitors, etc. Also, as in the NPC case, single supply can be used to generate multiple pole voltage levels. Many strategies for balancing the capacitor voltages have evolved over time [10], [11]. However, generating more voltage levels in a FC inverter requires larger number of capacitors. Interesting derivatives of this configura tion have been presented in [12] and [13], where more levels have been achieved by cross connecting the capacitors using additional switches. Operation of FC inverter with improved reliability has been presented in [18], where additional circuitry is provided to bypass the faulty cell. However, in this scheme, the devices have to be sufficientl overrated to operate at full power level when the faulty cell is bypassed. The operation of FC inverter with asymmetrical capacitor voltages to generate more voltage levels has been presented in [15]. In this configuration the number of voltage levels that can be achieved depends on the modulation index and the power factor.

The multilevel CHB inverter with isolated supplies presented in [5] has many advantages compared to the NPC and FC topologies. The CHB configuratio does not require clamping diodes and the input power is distributed among different input sources that makes it more suitable for certain applications [16]. One additional advantage of the CHB converter is that if any device fails in the H-bridges, the inverter can still be operated at reduced power level and, hence, this configuratio is fault tolerant to some extent [17], [18]. The concept of using CHBs with capacitors and their voltage balancing has been introduced in [19] and [20]. The advantages include more redundant states, better voltage balancing, lack of clamping diodes, and fault tolerant operational ability by bypassing the faulty H-bridge cells. This configuratio is especially suitable for applications like STATCOM. DC-voltage ratio control strategy for a CHB converter fed with a single-dc source is presented in [21]. With this control strategy, a higher number of levels in output voltage waveform can be achieved with capacitor voltage balancing in a limited range of load power factor. This scheme is very much suitable for grid-connected applications. A multilevel config uration with improved reliability has been presented in [22] and [23]. 


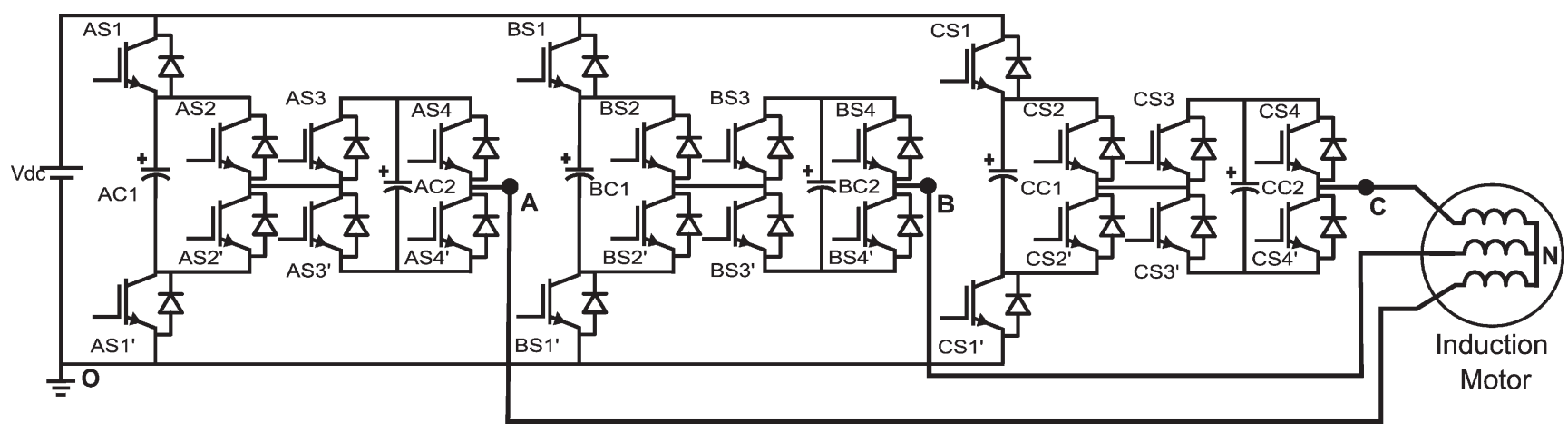

Fig. 1. Proposed three-phase power circuit formed by the connection of a three-phase flyin capacitor inverter with H-bridges in series.

Many other multilevel inverter configuration have been developed based on the three conventional (NPC, FC, and CHB) topologies. A configuratio in which two-level inverter is cascaded with multiple $\mathrm{H}$-bridges has been presented in [24], where more voltage levels can be generated. New multilevel inverter configuration for open-end winding induction motors, formed by cascading two-level inverters and capacitor-fed H-bridges are given in [25] and [26].

Five-level active neutral point clamped (ANPC) inverter topology [27] is another configuration which is a hybrid of FC topology and NPC configuration This fi e-level ANPC converter is being commercialized by ABB as the ACS2000 (up to $1.6 \mathrm{MW}$ ). The configuratio presented in [28] introduces the concept of integrating the cross-connected intermediate level [29] and the ANPC configuratio to form a hybrid configuration A hybrid derivative of the ANPC configuratio and $\mathrm{CHB}$ has been presented in [30]. Derivatives of CHB where different devices [Integrated Gate-Commutated Thyristor (IGCT) and insulated gate bipolar transistor (IGBT)] are used in such a way that the IGCT would switch at fundamental frequency and IGBT would switch at carrier frequency has been presented in [31]. The concept of a hybrid cascade converter topology with series-connected symmetrical and asymmetrical diode-clamped $\mathrm{H}$-bridge cells has been presented in [32]. The hybrid clamped multilevel inverter topology [33] is a hybrid of NPC topology and FC topology, which does not have neutral point fluctuation

The multilevel inverter proposed in this paper is a cascaded topology consisting of three-level FC inverters and capacitorfed H-bridges, in which balancing of the capacitor voltages are possible independently of the load power factor.

\section{Proposed Power Circuit}

As shown in Fig. 1, the proposed topology has a three-level $\mathrm{FC}$ inverter with dc bus voltage of $V_{\mathrm{DC}}$ and $\mathrm{FC}$ voltage equal to $V_{\mathrm{DC}} / 2$, which can generate voltages of $0, V_{\mathrm{DC}} / 2$, and $V_{\mathrm{DC}}$ with respect to point 0 . A capacitor-fed $\mathrm{H}$-bridge is cascaded to each phase of the inverter. The voltage across the H-bridge capacitor has to be maintained at $V_{\mathrm{DC}} / 4$. This combination can produce voltage levels of $0, V_{\mathrm{DC}} / 4, V_{\mathrm{DC}} / 2,3 V_{\mathrm{DC}} / 4, V_{\mathrm{DC}},-V_{\mathrm{DC}} / 4$, and $5 V_{\mathrm{DC}} / 4$. Out of these, the voltages $-V_{\mathrm{DC}} / 4$ and $5 V_{\mathrm{DC}} / 4$ are not used in the proposed inverter as they do not have redundant switching states to balance the capacitor voltages. The switch- ing states of the useful voltage levels and their effects on the capacitor voltages based on the current direction are given in Table I.

The capacitor voltages remain unaffected while producing the voltages $V_{\mathrm{DC}}$ and 0 . The capacitors can either be charged or discharged in any direction of the current for the voltages $V_{\mathrm{DC}} / 4, V_{\mathrm{DC}} / 2$, and $3 V_{\mathrm{DC}} / 4$ as shown in Figs. 2-4, respectively. In each phase, the switches $\mathrm{S} 1, \mathrm{~S} 2, \mathrm{~S} 3, \mathrm{~S} 4$ and $\mathrm{S} 1^{\prime}, \mathrm{S} 2^{\prime}, \mathrm{S} 3^{\prime}, \mathrm{S} 4^{\prime}$ are operated in complementary manner. The output voltage is based on the switching states that decide the path of the current fl w.

For voltage levels of $V_{\mathrm{DC}} / 4$ and $3 V_{\mathrm{DC}} / 4$, there are three redundant states. By switching between these three states the capacitors $\mathrm{C} 1$ and $\mathrm{C} 2$ can be charged or discharged for any direction of the current. The voltage level of $V_{\mathrm{DC}} / 2$ has two redundant states. By switching between them, $\mathrm{C} 1$ can be charged or discharged based on the current direction. When $V_{\mathrm{DC}} / 2$ is applied, the $\mathrm{C} 2$ is not affected. As the capacitors can be either charged or discharged by switching between the redundant states, based on the current direction, quick capacitor voltage balancing is possible, irrespective of the load power factor. To maintain the capacitor voltages at a f xed value, the capacitor voltages are sampled at regular intervals and a hysteresis controller is used to switch between the redundant states based on the current direction to balance the capacitor voltages.

Each pole can generate one of the f ve voltage levels $0, V_{\mathrm{DC}} / 4$, $V_{\mathrm{DC}} / 2,3 V_{\mathrm{DC}} / 4$, and $V_{\mathrm{DC}}$. The effective voltage space vector formed based on the three-phase pole voltages is given by

$$
V_{\mathrm{SV}}=V_{\mathrm{AO}}+V_{\mathrm{BO}} \angle 120^{\circ}-V_{\mathrm{CO}} \angle 120^{\circ}
$$

where $V_{\mathrm{SV}}$ is the voltage space vector and $V_{\mathrm{AO}}, V_{\mathrm{BO}}$, and $V_{\mathrm{CO}}$ are the pole voltages in the three phases $\mathrm{A}, \mathrm{B}$, and $\mathrm{C}$, respectively.

The f ve-level space vector diagram obtained for the combinations of the pole voltages of the three phases is shown in Fig. 5. There are 61 voltage vector locations possible for the fi e-level space vector structure. Many of the voltage vector locations have redundant switching state combinations of the pole voltages of three phases. The switching state combinations for a space vector sector of $60^{\circ}$ interval (as shown shaded in Fig. 5) are presented in Table II. The space vector locations 37, 38, 39, $40,41,42,43,44,45,46,47,48,49,50,51,52,53,54,55$, $56,57,58,59$, and 60 are located on the outermost hexagon and these vectors can be obtained with only one pole-voltage 
TABLE I

VARIOUS VOlTAGE LEVELS AND CAPACITOR STATES BASED ON THE SWITCHING STATES

\begin{tabular}{|c|c|c|c|c|c|}
\hline S.No & $\begin{array}{c}\text { Switch State } \\
(\mathbf{S 1}, \mathbf{S} 2, \mathbf{S 3}, \mathbf{S 4})^{b}\end{array}$ & $V_{A O}$ & $I_{A}^{a}$ & $\begin{array}{l}\text { Cap C1 } \\
\left(V_{D C} / \mathbf{2}\right)\end{array}$ & $\begin{array}{l}\text { Cap C2 } \\
\left(V_{D C} / \mathbf{4}\right)\end{array}$ \\
\hline 1 & $(0,0,1,0)$ & $-V_{D C} / 4$ & + & No effect & Charge \\
\hline 2 & $(0,0,0,0)$ & 0 & + & No effect & No effect \\
\hline 3 & $(0,0,1,1)$ & 0 & + & No effect & No effect \\
\hline 4 & $(0,0,0,1)$ & $V_{D C} / 4$ & + & No effect & Discharge \\
\hline 5 & $(0,1,1,0)$ & $V_{D C} / 4$ & + & Discharge & Charge \\
\hline 6 & $(1,0,1,0)$ & $V_{D C} / 4$ & + & Charge & Charge \\
\hline 7 & $(1,0,0,0)$ & $V_{D C} / 2$ & + & Charge & No effect \\
\hline 8 & $(0,1,0,0)$ & $V_{D C} / 2$ & + & Discharge & No effect \\
\hline 9 & $(0,1,1,1)$ & $V_{D C} / 2$ & + & Discharge & No effect \\
\hline 10 & $(1,0,1,1)$ & $V_{D C} / 2$ & + & Charge & No effect \\
\hline 11 & $(0,1,0,1)$ & $3 V_{D C} / 4$ & + & Discharge & Discharge \\
\hline 12 & $(1,0,0,1)$ & $3 V_{D C} / 4$ & + & Charge & Discharge \\
\hline 13 & $(1,1,1,0)$ & $3 V_{D C} / 4$ & + & No effect & Charge \\
\hline 14 & $(1,1,1,1)$ & $V_{D C}$ & + & No effect & No effect \\
\hline 15 & $(1,1,0,0)$ & $V_{D C}$ & + & No effect & No effect \\
\hline 16 & $(1,1,0,1)$ & $5 V_{D C} / 4$ & + & No effect & Discharge \\
\hline 17 & $(0,0,1,0)$ & $-V_{D C} / 4$ & - & No effect & Discharge \\
\hline 18 & $(0,0,0,0)$ & 0 & - & No effect & No effect \\
\hline 19 & $(0,0,1,1)$ & 0 & - & No effect & No effect \\
\hline 20 & $(0,0,0,1)$ & $V_{D C} / 4$ & - & No effect & Charge \\
\hline 21 & $(0,1,1,0)$ & $V_{D C} / 4$ & - & Charge & Discharge \\
\hline 22 & $(1,0,1,0)$ & $V_{D C} / 4$ & - & Discharge & Discharge \\
\hline 23 & $(1,0,0,0)$ & $V_{D C} / 2$ & - & Discharge & No effect \\
\hline 24 & $(0,1,0,0)$ & $V_{D C} / 2$ & - & Charge & No effect \\
\hline 25 & $(0,1,1,1)$ & $V_{D C} / 2$ & - & Charge & No effect \\
\hline 26 & $(1,0,1,1)$ & $V_{D C} / 2$ & - & Discharge & No effect \\
\hline 27 & $(0,1,0,1)$ & $3 V_{D C} / 4$ & - & Charge & Charge \\
\hline 28 & $(1,0,0,1)$ & $3 V_{D C} / 4$ & - & Discharge & Charge \\
\hline 29 & $(1,1,1,0)$ & $3 V_{D C} / 4$ & - & No effect & Discharge \\
\hline 30 & $(1,1,1,1)$ & $V_{D C}$ & - & No effect & No effect \\
\hline 31 & $(1,1,0,0)$ & $V_{D C}$ & - & No effect & No effect \\
\hline 32 & $(1,1,0,1)$ & $5 V_{D C} / 4$ & - & No effect & Charge \\
\hline
\end{tabular}

${ }^{a}(+)$ indicates the current direction from $\mathrm{A}$ to $\mathrm{O}$ of the load.

${ }^{b}(1)$ indicates ON state and $(0)$ indicates OFF state of the switch.

combination. The locations 19, 20, 21, 22, 23, 24, 25, 26, 27, 28, $29,30,31,32,33,34,35$, and 36 are located in the third largest hexagon and have two redundant states. The locations $7,8,9$, $10,11,12,13,14,15,16,17$, and 18 are located in the second largest hexagon and have three redundant states. The space vector locations $1,2,3,4,5$, and 6 are located in smallest hexagon and have four redundant states. The zero vector location 0 has fi e redundant states in total. The redundancies in the switching state combination for realizing a particular voltage space vector location can be effectively used for PWM control to minimize the inverter switching transitions.

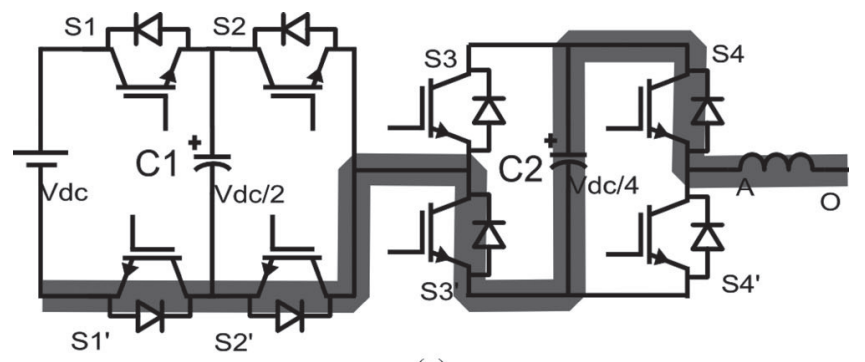

(a)

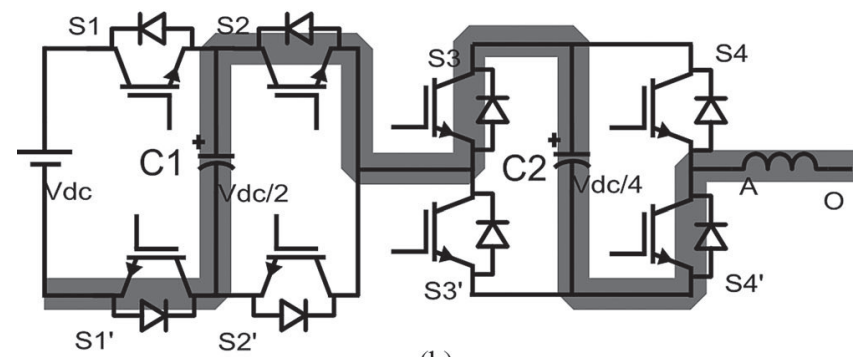

(b)

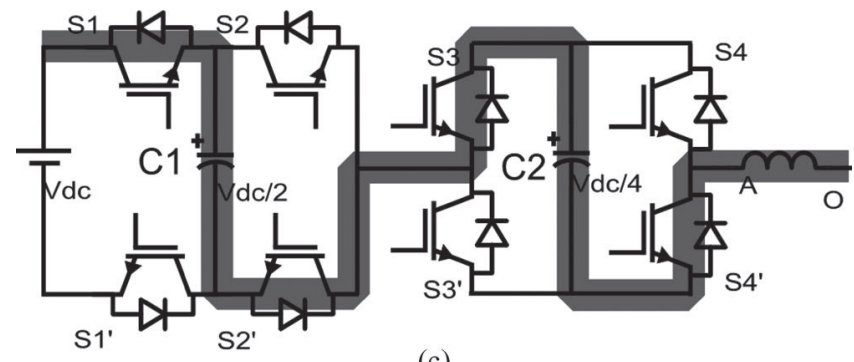

(c)

Fig. 2. Switch transitions and current path for the redundant states of $V_{\mathrm{DC}} / 4$ for a phase. (a) Current path for switch state of $(0,0,0,1)$, (b) Current path for switch state of $(0,1,1,0)$. (c) Current path for switch state of $(1,0,1,0)$.

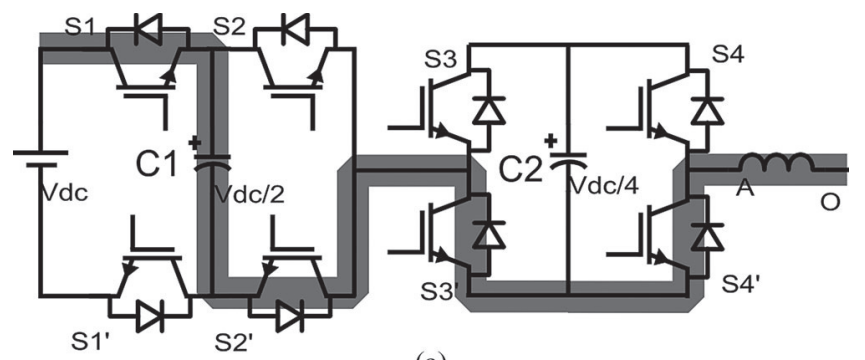

(a)

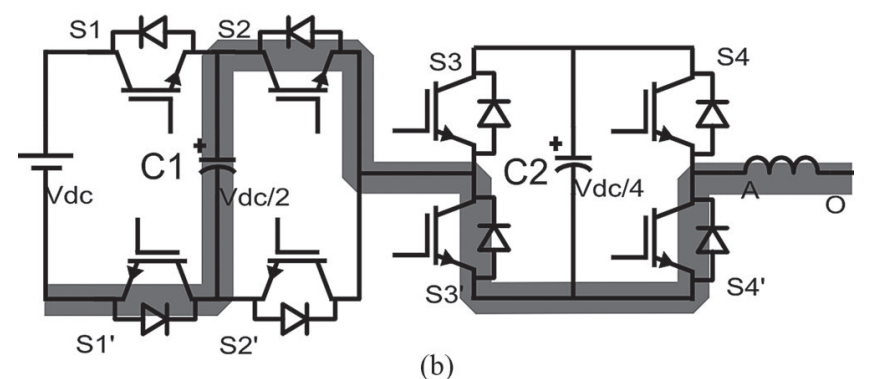

Fig. 3. Switch transitions and current path for the redundant states of $V_{\mathrm{DC}} / 2$ for a phase. (a) Current path for switch state of $(1,0,0,0)$. (b) Current path for switch state of $(0,1,0,0)$. 


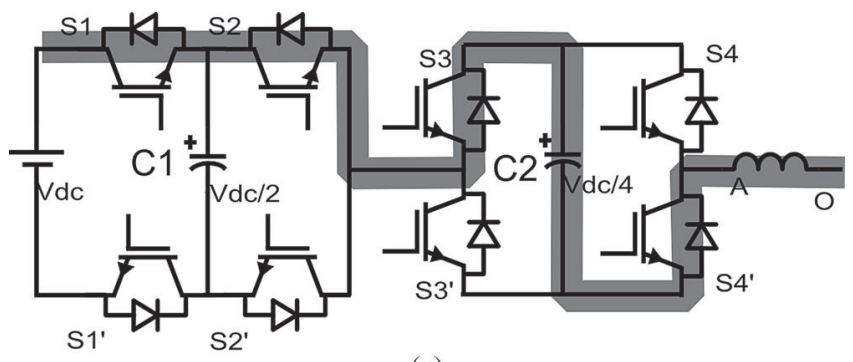

(a)

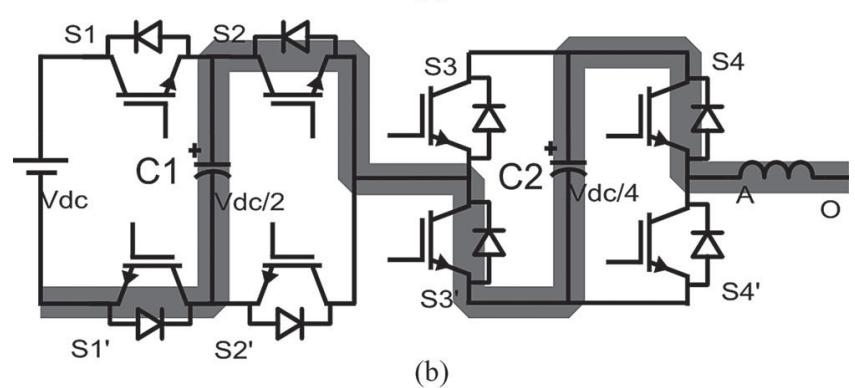

(b)

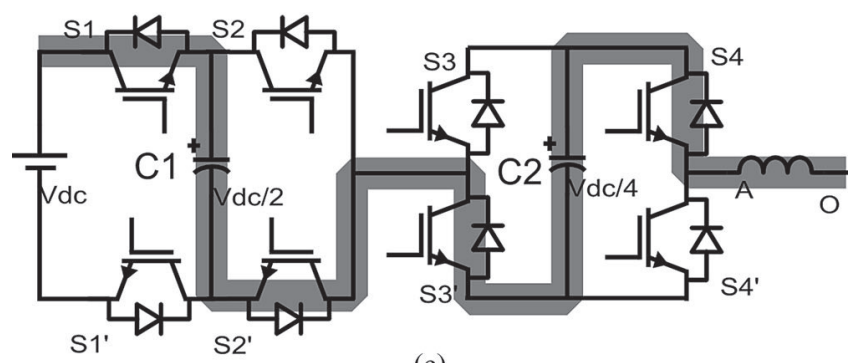

(c)

Fig. 4. Switch transitions and current path for the redundant states of $3 V_{\mathrm{DC}} / 4$ for a phase. (a) Current path for switch state of $(1,1,1,0)$. (b) Current path for switch state of $(0,1,0,1)$. (c) Current path for switch state of $(1,0,0,1)$.

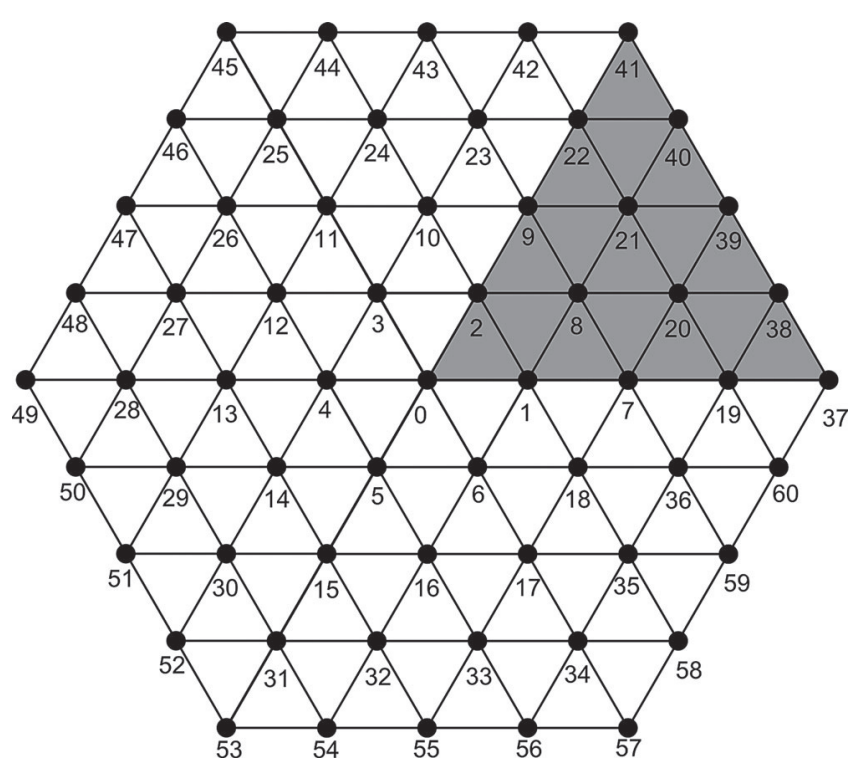

Fig. 5. Space Vector polygon formed with the proposed fi e-level inverter.

\section{SALIENT FEATURES}

The proposed three-phase topology uses 12 switches of voltage rating $V_{\mathrm{DC}} / 2$ and 12 switches of voltage rating $V_{\mathrm{DC}} / 4$ (total
TABLE II

Voltages Formed as a Result OF THE THREe PHASES FOR $60^{\circ}$ INTERVAL

\begin{tabular}{|c|c|c|}
\hline State No & Combinations of three phases ${ }^{a}$ & Combinations \\
\hline 0 & $(0,0,0)(1,1,1)(2,2,2)(3,3,3)(4,4,4)$ & 5 \\
\hline 1 & $(1,0,0)(2,1,1)(3,2,2)(4,3,3)$ & 4 \\
\hline 2 & $(1,1,0)(2,2,1)(3,3,2)(4,4,3)$ & 4 \\
\hline 7 & $(2,0,0)(3,1,1)(4,2,2)$ & 3 \\
\hline 8 & $(2,1,0)(3,2,1)(4,3,2)$ & 3 \\
\hline 9 & $(2,2,0)(3,3,1)(4,4,2)$ & 3 \\
\hline 19 & $(3,0,0)(4,1,1)$ & 2 \\
\hline 20 & $(3,1,0)(4,2,1)$ & 2 \\
\hline 21 & $(3,2,0)(4,3,1)$ & 2 \\
\hline 22 & $(3,3,0)(4,4,1)$ & 2 \\
\hline 37 & $(4,0,0)$ & 1 \\
\hline 38 & $(4,1,0)$ & 1 \\
\hline 39 & $(4,2,0)$ & 1 \\
\hline 40 & $(4,3,0)$ & 1 \\
\hline 41 & $(4,4,0)$ & 1 \\
\hline
\end{tabular}

a $(a, b, c)$ where $a, b, c$ values of $0,1,2,3$, and 4 implies pole voltages of $0, V_{\mathrm{DC}} / 4$,

$V_{\mathrm{DC}} / 2,3 V_{\mathrm{DC}} / 4$, and $V_{\mathrm{DC}}$, respectively.

24 switches), where $V_{\mathrm{DC}}$ is the dc bus voltage. It has two capacitors per phase, one is rated at $V_{\mathrm{DC}} / 2$ and the other is rated at $V_{\mathrm{DC}} / 4$. So in total, the proposed three-phase configuratio requires only six capacitors, while the conventional fi e-level $\mathrm{FC}$ inverter requires nine capacitors. The asymmetrical FC configuratio shown in [15] requires 12 switches of rating $V_{\mathrm{DC}} / 4$, six switches of rating $V_{\mathrm{DC}} / 2$, three capacitors of rating $V_{\mathrm{DC}} / 4$, and three capacitors of rating $V_{\mathrm{DC}} / 2$ for a three-phase inverter. However, this configuratio has limited range of power factor for fi e-level operation. The conventional fi e-level CHB configu ration uses six isolated power supplies of voltage rating $V_{\mathrm{DC}} / 4$ and 24 switches of voltage rating $V_{\mathrm{DC}} / 4$. However, the proposed configuratio uses just one dc source of magnitude $V_{\mathrm{DC}}$. The fi e-level NPC inverter requires four capacitors of rating $V_{\mathrm{DC}} / 4$, 36 clamping diodes of voltage rating $V_{\mathrm{DC}} / 4$ and 24 switches of rating $V_{\mathrm{DC}} / 4$. However, the proposed topology does not require any clamping diode.

The f ve-level ANPC topology [27] requires three capacitors of voltage rating $V_{\mathrm{DC}} / 4$ for three phases and two capacitors of voltage rating $V_{\mathrm{DC}} / 2$. However, this configuratio has neutral point fluctuation The proposed configuratio does not have any such problem as it has FC front end. The hybrid clamped multilevel topology requires more number of switches and clamping diodes as compared to the proposed configuration A comparison of the proposed topology with the other fi e-level inverter topologies can be found in the Table III. Another important advantage of the proposed scheme is that if one of the devices in the $\mathrm{H}$ bridge fails, the H-bridge can be bypassed through a fast bypass switch or by routing the current through the devices in the complementary path and the inverter can work in three-level mode at the full power rating. For example, if S3 or S4 fails then the current can be routed through $\mathrm{S}^{\prime}$ and $\mathrm{S}^{\prime}$ by switching them $\mathrm{ON}$ and removing the gating signals to $\mathrm{S} 3$ and $\mathrm{S} 4$ or vice versa. 
TABLE III

COMPARISON BetweEn NPC,FC,CHB, AND Proposed CONFIGURATION

\begin{tabular}{|c||c||c||c||c||c||c|}
\hline Component & NPC $^{a}$ & $\mathbf{F C}^{b}$ & $\mathbf{C H B}^{c}$ & ANPC $^{d}$ & HCMLI $^{e}$ & PI $^{f}$ \\
\hline Capacitor $\left(V_{D C} / 4\right)$ & 4 & 3 & 0 & 3 & 13 & 3 \\
\hline Capacitor $\left(V_{D C} / 2\right)$ & 0 & 3 & 0 & 2 & 0 & 3 \\
\hline Capacitor $\left(3 V_{D C} / 4\right)$ & 4 & 3 & 0 & 0 & 0 & 3 \\
\hline Switches $\left(V_{D C} / 4\right)$ & 24 & 24 & 24 & 12 & 42 & 12 \\
\hline Switches $\left(V_{D C} / 2\right)$ & 0 & 0 & 0 & 12 & 0 & 12 \\
\hline Clamping diodes $\left(V_{D C} / 4\right)$ & 36 & 0 & 0 & 0 & 18 & 0 \\
\hline Power Supplies $\left(V_{D C} / 4\right)$ & 0 & 0 & 6 & 0 & 0 & 0 \\
\hline Power Supplies $\left(V_{D C} / 2\right)$ & 0 & 0 & 0 & 0 & 0 & 0 \\
\hline Power Supplies $\left(V_{D C}\right)$ & 1 & 1 & 0 & 1 & 1 & 1 \\
\hline
\end{tabular}

${ }^{\mathrm{a}} \mathrm{NPC}$ inverter.

FC inverter.

Simplified active NPC inverter [27]

Hybrid clamped multilevel inverter [33].

Proposed inverter configuration.

\section{EXPERIMENTAL RESULTS}

The proposed fi e-level inverter circuit has been tested on a $400 \mathrm{~V}, 3 \mathrm{~kW}, 50 \mathrm{~Hz}$, Y-connected, induction motor drive with $V / f$ control scheme at a switching frequency of $1 \mathrm{kHz}$. The hardware setup for the controller consists of a TMS320F2812 digital signal processing (DSP) platform and a Digilent SPARTAN-3 XC3S200 field-programmabl gate arrays (FPGA). The capacitor voltages of all the three phases are sampled at every switching cycle and compared with the reference values $\left(V_{\mathrm{DC}} / 2\right.$ for $\mathrm{C} 1$ and $V_{\mathrm{DC}} / 4$ for $\mathrm{C} 2$ ). Level-shifted carrier-based space-vector pulse-width modulation algorithm given in [34] has been used to generate the PWM signals. The PWM output along with the carrier level data for all the three phases, hysteresis controller outputs for all the capacitors, and current direction data for all the three phases are sent out to the FPGA by the DSP. FPGA generates the gating signals to the inverter switches based on the inputs from the DSP. The logic for generating a dead time of $3 \mathrm{~s}$ has been implemented in FPGA itself. The inverter dc-link voltage is set to $200 \mathrm{~V}$. The hysteresis limit for the capacitors is set at $5 \%$ of the respective capacitor voltage. The capacitors are sized suitably so that the voltage of the capacitors would not cross the hysteresis limits in two switching cycles at full load current.

The capacitance $C$ is determined by

$$
C=\frac{2\left(i_{L} T_{S}\right)}{\Delta V_{C}}
$$

where $\Delta V_{C}$ is the capacitor voltage ripple, $T_{S}$ is the sampling time, and $i_{L}$ is the peak load current. The capacitor voltages are sampled every switching cycle ( $1 \mathrm{~ms}$ in this case). A capacitance value of $4400 \mu \mathrm{F}$ has been used for $\mathrm{C} 1$ and $\mathrm{C} 2$ for all the three phases. The motor is run at various modulation indexes and frequencies at no load.

The motor is run at modulation indexes $\left(V_{\mathrm{SV}} / V_{\mathrm{DC}}\right)$ of $0.2,0.4$, 0.6 , and 0.8 at frequencies of $10,20,30$, and $40 \mathrm{~Hz}$, respectively, at no load. The phase voltage waveform along with the phase current and the voltage ripple of the capacitors $\mathrm{C} 1$ and $\mathrm{C} 2$ for frequencies of 10, 20, 30, and $40 \mathrm{~Hz}$ are shown in Fig. 6(a)-(d), respectively. The pole voltage waveform along with the phase current at no load operation and the voltage ripple of capacitors

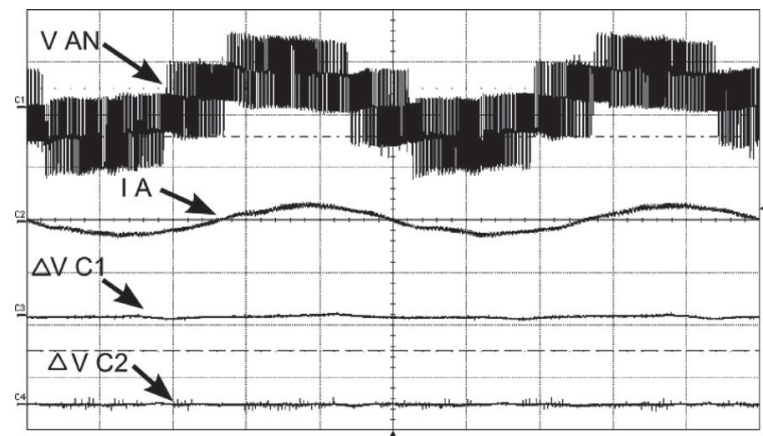

(a)

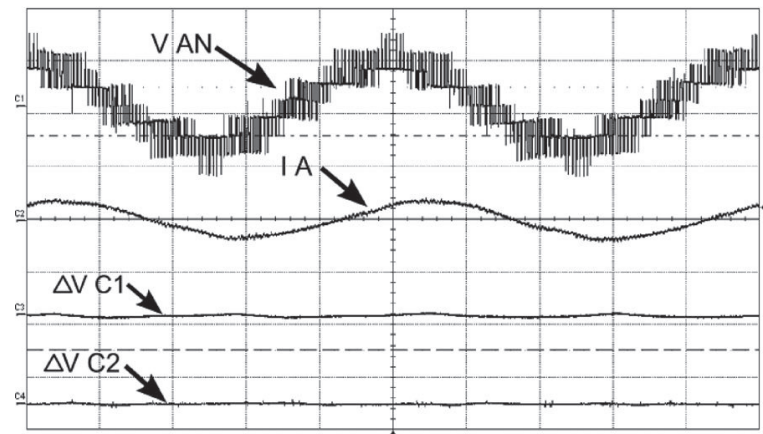

(b)

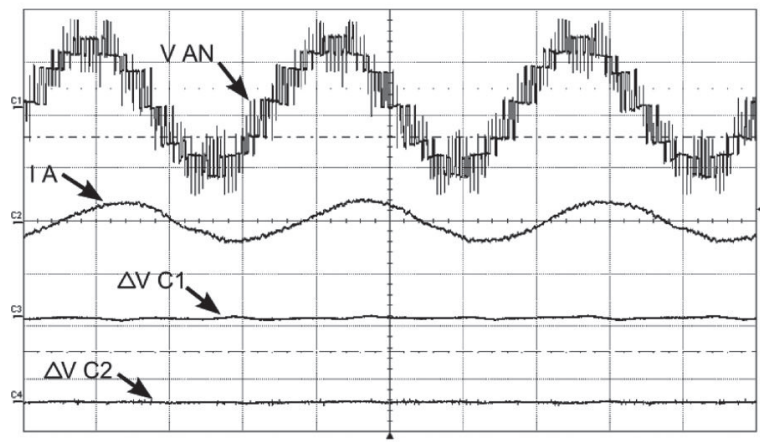

(c)

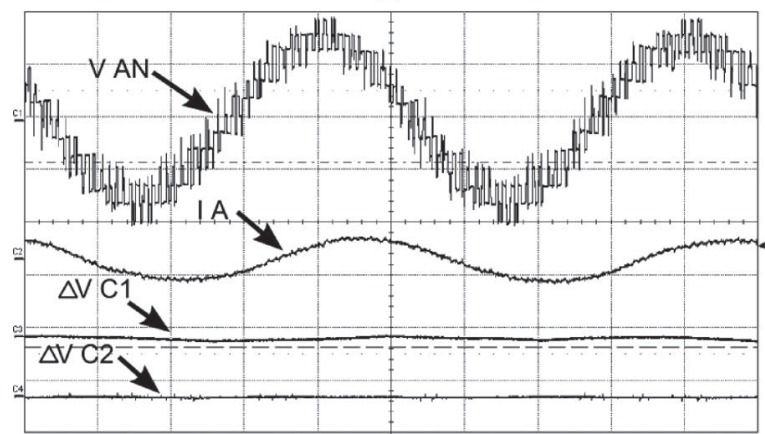

(d)

Fig. 6. Phase voltage $V_{\mathrm{AN}}$, phase current $I_{A}$ and capacitor voltage ripple for different modulation indexes for phase $\mathrm{A}: \Delta V_{\mathrm{C} 1}=5 \mathrm{~V} /$ div; $\Delta V_{\mathrm{C} 2}=10 \mathrm{~V} /$ div; $I_{A}=2 \mathrm{~A} /$ div. (a) $10 \mathrm{~Hz}$ with modulation index of $0.2\left(V_{\mathrm{AN}}=50 \mathrm{~V} / \mathrm{div}\right.$, time $=$ $20 \mathrm{~ms} / \mathrm{div})$. (b) $20 \mathrm{~Hz}$ with modulation index of $0.4\left(V_{\mathrm{AN}}=100 \mathrm{~V} / \mathrm{div}\right.$, time $=$ $10 \mathrm{~ms} / \mathrm{div})$. (c) $30 \mathrm{~Hz}$ with modulation index of $0.6\left(V_{\mathrm{AN}}=100 \mathrm{~V} / \mathrm{div}\right.$, time $=10 \mathrm{~ms} / \mathrm{div})$. (d) $40 \mathrm{~Hz}$ with modulation index of $0.8\left(V_{\mathrm{AN}}=100 \mathrm{~V} / \mathrm{div}\right.$, time $=5 \mathrm{~ms} /$ div) .

$\mathrm{C} 1$ and $\mathrm{C} 2$ at frequencies of $10,20,30$, and $40 \mathrm{~Hz}$ are shown in Fig. 7(a)-(d), respectively. The capacitor voltage ripple is less than $2.5 \mathrm{~V}$ for both $\mathrm{C} 1$ and $\mathrm{C} 2$. This validates the capacitor voltage balancing algorithm. 


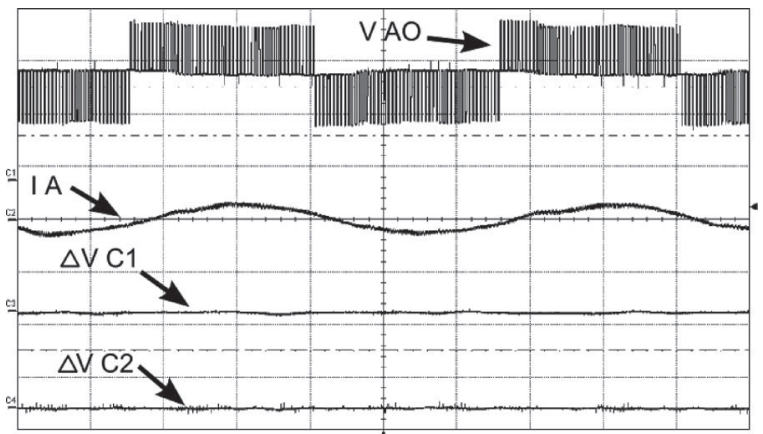

(a)

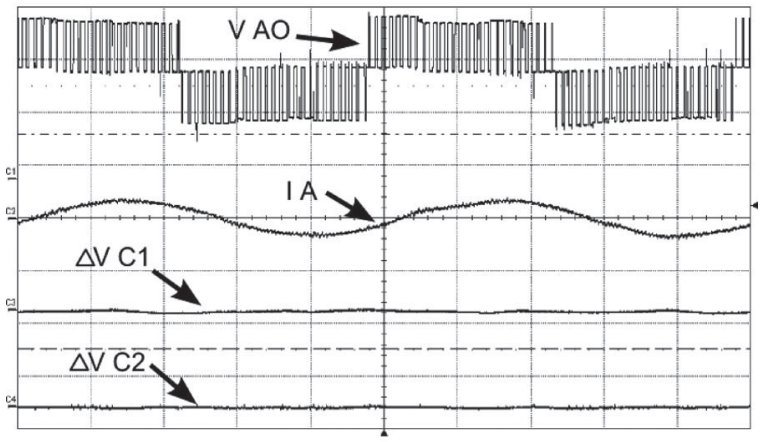

(b)

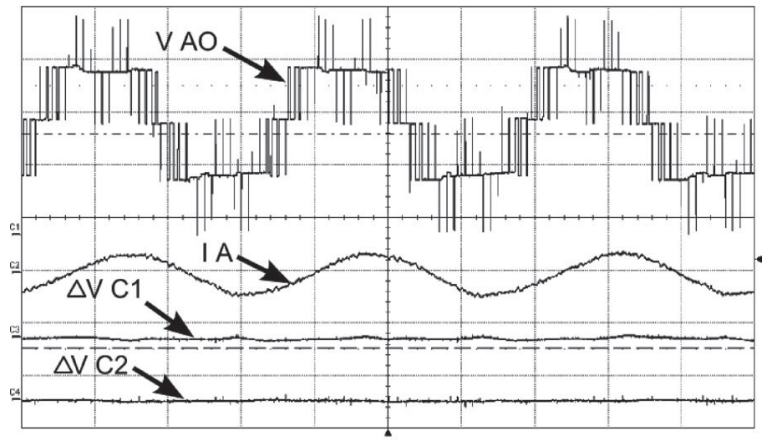

(c)

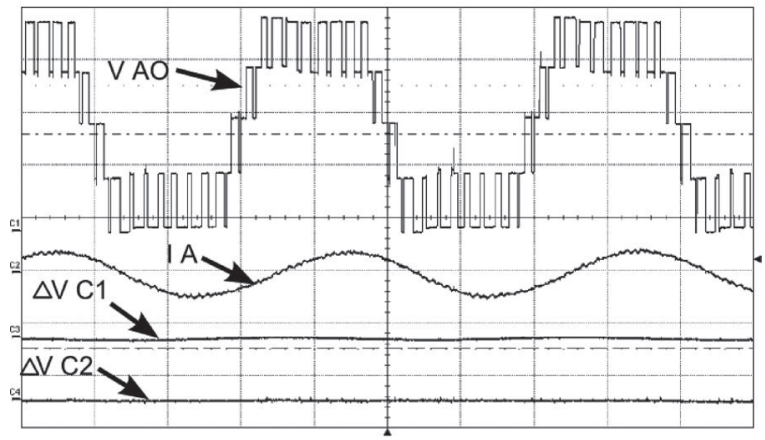

(d)

Fig. 7. Pole voltage $V_{\mathrm{AO}}$, phase current $I_{A}$ and capacitor voltage ripple for different modulation indexes for phase A: $\Delta V_{\mathrm{C} 1}=5 \mathrm{~V} / \mathrm{div} ; \Delta V_{\mathrm{C} 2}=10 \mathrm{~V} /$ div; $I_{A}=2 \mathrm{~A} /$ div. (a) $10 \mathrm{~Hz}$ with modulation index of $0.2\left(\mathrm{~V}_{\mathrm{AO}}=50 \mathrm{~V} / \mathrm{div}\right.$, time $=$ $20 \mathrm{~ms} / \mathrm{div})$. (b) $20 \mathrm{~Hz}$ with modulation index of $0.4\left(V_{\mathrm{AO}}=100 \mathrm{~V} / \mathrm{div}\right.$, time $=$ $10 \mathrm{~ms} / \mathrm{div})$. (c) $30 \mathrm{~Hz}$ with modulation index of $0.6\left(V_{\mathrm{AO}}=100 \mathrm{~V} / \mathrm{div}\right.$, and time $=10 \mathrm{~ms} / \mathrm{div})$. (d) $40 \mathrm{~Hz}$ with modulation index of $0.8\left(V_{\mathrm{AO}}=100 \mathrm{~V} / \mathrm{div}\right.$, time $=5 \mathrm{~ms} / \mathrm{div})$.

The motor is accelerated from $10-40 \mathrm{~Hz}$ in $5 \mathrm{~s}$ at no load. The phase voltage, phase current, and the capacitor voltages are shown in Fig. 8. It can be observed that the dc voltages of the

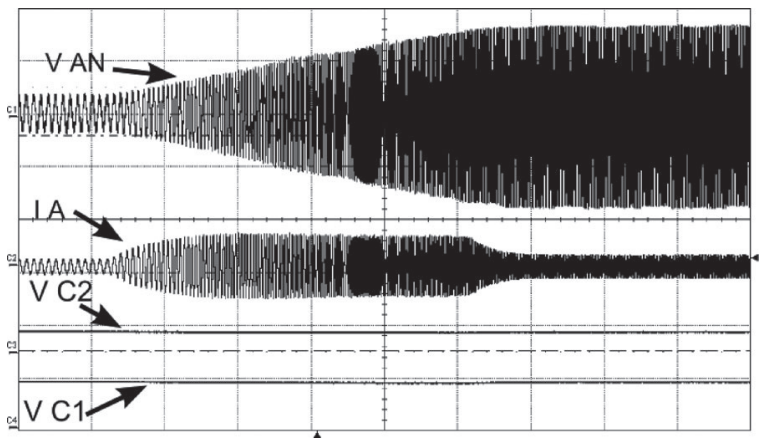

Fig. 8. Rapid acceleration of motor from 10 to $40 \mathrm{~Hz}$ in $5.5 \mathrm{~s}$. Capacitor voltage remains constant. $V_{\mathrm{AN}}$ (phase voltage): $200 \mathrm{~V} / \mathrm{div}, I_{A}$ (phase current): $2 \mathrm{~A} / \mathrm{div}, V_{\mathrm{C} 1}\left(V_{\mathrm{DC}} / 2\right.$ capacitor DC voltage): $100 \mathrm{~V} / \mathrm{div}, V_{\mathrm{C} 2}\left(V_{\mathrm{DC}} / 4\right.$ capacitor DC voltage): $100 \mathrm{~V} /$ div, and time scale: $1 \mathrm{~s} /$ div.

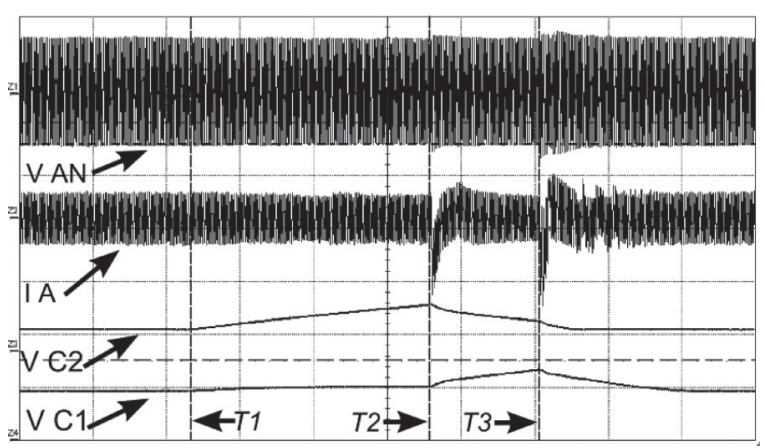

Fig. 9. Capacitor balancing operation. The balancing logic has been disabled at T1. $\mathrm{C} 1$ balancing has been enabled at $\mathrm{T} 2$ and $\mathrm{C} 2$ balancing has been enabled at T3. $V_{\mathrm{A} \mathrm{N}}$ (phase voltage): $200 \mathrm{~V} / \mathrm{div}, I_{A}$ (phase current): $2 \mathrm{~A} / \mathrm{div}, V_{\mathrm{C} 1}$ $\left(V_{\mathrm{DC}} / 2\right.$ capacitor DC voltage): $100 \mathrm{~V} / \mathrm{div}, V_{\mathrm{C} 2}\left(V_{\mathrm{DC}} / 4\right.$ capacitor DC voltage): $100 \mathrm{~V} /$ div, and time scale: $2 \mathrm{~s} /$ div.

capacitors remain balanced even during sudden acceleration. In Fig. 9, the effect of disabling the capacitor voltage balancing algorithm is shown. The capacitor voltage balancing algorithm has been disabled at $\mathrm{T} 1$ and enabled for $\mathrm{C} 1$ at $\mathrm{T} 2$ and $\mathrm{C} 3$ at $\mathrm{T} 3$. It can be observed that the capacitor voltages are restored to preset values once the capacitor voltage balancing algorithm has been enabled. These experimental results verify the performance of the proposed fi e-level inverter topology.

\section{CONCLUSION}

In this paper, a new three-phase f ve-level inverter topology with a single-dc source has been proposed. This configuratio is formed by cascading a three-level FC inverter and capacitor-fed $\mathrm{H}$-bridges. The key advantages of this topology compared to the conventional topologies include reduced number of devices and simple control. An important feature of this inverter is the ability to balance the capacitor voltages irrespective of load power factor. Another advantage of this inverter is that if one of the H-bridge fails, it can operate as a three-level inverter at full power rating by bypassing the H-bridge. This feature of the inverter improves the reliability of the system.

The proposed configuratio has been analyzed and experimentally verifie for various modulation indexes and frequencies by running a $3-\mathrm{kW}$ squirrel cage induction motor in $V / f$ 
control mode, at no load. The working of the capacitor balancing algorithm has been tested. The stable operation of the inverter for various modulation indexes and stability of the inverter voltage levels during rapid acceleration have been validated experimentally.

\section{REFERENCES}

[1] J. Rodriguez, S. Bernet, B. Wu, J. O. Pontt, and S. Kouro, "Multilevel voltage-source-converter topologies for industrial medium-voltage drives," IEEE Trans. Ind. Electron., vol. 54, no. 6, pp. 2930-2945, Dec. 2007.

[2] S. Kouro, M. Malinowski, K. Gopakumar, J. Pou, L. G. Franquelo, B. Wu, J. Rodriguez, M. A. Perez, and J. I. Leon, "Recent Advances and Industrial Applications of Multilevel Converters," IEEE Trans. Ind. Electron., vol. 57, no. 8, pp. 2553-2580, Aug. 2010.

[3] A. Nabae, I. Takahashi, and H. Akagi, "A new neutral-point-clamped PWM inverter,” IEEE Trans. Ind. Appl., vol. IA-17, no. 5, pp. 518-523, Sep. 1981.

[4] T. A. Meynard and H. Foch, "Multi-level conversion: High voltage choppers and voltage-source inverters," in Proc. IEEE 23rd Annu. Power Electron. Spec. Conf., Jun. 29-Jul. 3, 1992, vol. 1, pp. 397-403.

[5] M. Marchesoni, M. Mazzucchelli, and S. Tenconi, "A non-conventional power converter for plasma stabilization," in Proc. IEEE 19th Annu. Power Electron. Spec. Conf. (PESC'88) Rec., Apr. 11-14, vol. 1, pp. 122-129.

[6] L. Lin;Y. Zou; Z. Wang and H. Jin, "A simple neutral-point voltage balancing control method for three-level NPC PWM VSI inverters," in Proc. IEEE Int. Conf. Electr. Mach. Drives, May 15, 2005, pp. 828-833.

[7] S. Guanchu, K. Lee, L. Xinchun, and L. Chongbo, "New neutral point balancing strategy for f ve-level diode clamped converters used in STATCOM of wind energy conversion systems," in Proc. IEEE 6th Int. Power Electron. Motion Control Conf., May 17-20, 2009, pp. 2354-2358.

[8] S. Busquets-Monge, S. Somavilla, J. Bordonau, and D. Boroyevich, "Capacitor voltage balance for the neutral-point-clamped converter using the virtual space vector concept with optimized spectral performance," IEEE Trans. Power Electron., vol. 22, no. 4, pp. 1128-1135, Jul. 2007.

[9] G. Mondal, K. Gopakumar, P. N. Tekwani, and E. Levi, "A multi-level inverter structure with cascaded two-level and three-level inverters for IM drive with CMV elimination and dc-link capacitor voltage balancing," in Proc. IEEE Conf. Rec. Ind. Appl. Conf., Oct. 2007, pp. 589-596.

[10] B. P. McGrath and D. G. Holmes, "Enhanced voltage balancing of f ying capacitor multilevel converter using phase disposition (PD) modulation," IEEE Trans. Power Electron., vol. 26, no. 7, pp. 1933-1942, Jul. 2011.

[11] A. Shukla, A. Gosh, and A. Josh, "Natural balancing of f ying capacitor voltages in multicell inverter under PD carrier-based PWM," IEEE Trans. Power Electron., vol. 26, no. 7, pp. 1682-1693, Jul. 2011.

[12] T. Chaudhari and A. Rufer, "Modeling and control of the cross-connected inermediate level voltage source inverter," IEEE Trans. Ind. Electron., vol. 57, no. 8, pp. 2597-2604, Aug. 2010.

[13] T. Chaudhari, A. Rufer, and P. K. Steimer, "The common cross connected stage for the 5 L ANPC medium voltage multilevel inverter," IEEE Trans. Ind. Electron., vol. 57, no. 8, pp. 2279-2286, Aug. 2010.

[14] X. Kou, K. A. Corzine, and Y. L. Familiant, "A unique fault-tolerant design for f ying capacitor multilevel inverter," IEEE Trans. Power Electron., vol. 19, no. 4, pp. 979-987, Jul. 2004.

[15] J. Huang and K. A. Corzine, "Extended operation of fying capacitor multilevel inverters," IEEE Trans. Power Electron., vol. 21, no. 1, pp. 140 147, Jan. 2006.

[16] M. Malinowski, K. Gopakumar, J. Rodriguez, and M. A. Perez, “A survey on cascaded multilevel inverters," IEEE Trans. Ind. Electron., vol. 57, no. 7, pp. 2197-2206, Jul. 2010

[17] Wenchao Song and A. Q. Huang, "Fault-tolerant design and control strategy for cascaded h-bridge multilevel converter-based STATCOM," IEEE Trans. Ind. Electron., vol. 57, no. 8, pp. 2700-2708, Aug. 2010.

[18] P. Lezana, J. Pou, T. A. Meynard, J. Rodriguez, S. Ceballos, and F. Richardeau, "Survey on fault operation on multilevel inverters," IEEE Trans. Ind. Electron., vol. 57, no. 7, pp. 2207-2218, Jul. 2010

[19] Z. Du, L. M. Tolbert, J. N. Chiasson, B. Ozpineci, H. Li, and A. Q. Huang, "Hybrid cascaded H-bridges multilevel motor drive control for electric vehicles," in Proc. IEEE 37th Power Electron. Spec. Conf., Jun. 18-22, 2006, pp. 1-6.

[20] J. N. Chiasson, B. Ozpineci, and L. M. Tolbert, "A f ve-level three-phase hybrid cascade multilevel inverter using a single-dc source for a PM synchronous motor drive," in Proc. 22nd Annu. IEEE Appl. Power Electron. Conf., Feb. 25-Mar. 1, 2007, pp. 1504-1507.

[21] S. Vazquez, J. I. Leon, L. G. Franquelo, J. J. Padilla, and J. M. Carrasco, "DC-voltage-ratio control strategy for multilevel cascaded converters fed with a single DC source," IEEE Trans. Ind. Electron., vol. 56, no. 2, pp. 2513-2521, Jul. 2009

[22] M. Hagiwara, R. Maeda, and H. Akagi, "Control and analysis of the modular multilevel cascade converter based on double-star chopper-cells (MMCCDSCC)," IEEE Trans. Power Electron., vol. 26, no. 6, pp. 16491658, Jul. 2011.

[23] B. P. McGrath and D. G. Holmes, "A medium-voltage motor drive with a modular multilevel PWM inverter," IEEE Trans. Power Electron., vol. 25, no. 7, pp. 1786-1799, Jul. 2010.

[24] S. Mekhilef and M. N. Abdul Kadir, "Voltage control of three-stage hybrid multilevel inverter using vector tranformation," IEEE Trans. Power Electron., vol. 25, no. 10, pp. 2599-2606, Oct. 2010.

[25] K. Sivakumar, A. Das, R. Ramchand, C. Patel, and K. Gopakumar, "A hybrid multilevel inverter topology for an open-end winding inductionmotor drive using two-level inverters in series with a capacitor-fed $\mathrm{H}$ bridge cell," IEEE Trans. Ind. Electron., vol. 56, no. 11, pp. 3707-3714, Nov. 2010.

[26] P. P. Rajeevan, K. Sivakumar, C. Patel, R. Ramchand, and K. Gopakumar, "A seven-level inverter topology for induction motor drive using twolevel inverters and floatin capacitor fed H-bridges," IEEE Trans. Power Electron., vol. 26, no. 6, pp. 1733-1740, Jun. 2011.

[27] P. Barbosa, P. Steimer, J. Steinke, L. Meysenc, M. Winkelnkemper, and N. Celanovic, "Active neutral-point-clamped multilevel converters," in Proc. IEEE 36th Power Electron. Spec. Conf., Jun. 16, 2005, pp. 2296 2301.

[28] T. Chaudhuri, P. Steimer, and A. Rufer, "Introducing the common cross connected stage (C3S) for the 5L ANPC multilevel inverter," in Proc. IEEE Power Electron. Spec. Conf., Jun. 15-19, 2008, pp. 167-173.

[29] T. Chaudhuri, P. Barbosa, P. Steimer, and A. Rufer, "Cross-connected intermediate level (CCIL) voltage source inverter," in Proc. IEEE Power Electron. Spec. Conf., Jun. 17-21, 2007, pp. 490-496.

[30] M. Veenstra and A. Rufer, "Control of a hybrid asymmetric multi-level inverter for competitive medium-voltage industrial drives," in Proc. 38th IAS Annu. Meet.. Conf. Rec. Ind. Appl. Conf., Oct. 12-16, 2003, vol. 1, pp. 190-197.

[31] M. D. Manjrekar, P. Steimer, and T. A. Lipo, "Hybrid multilevel power conversion system: A competitive solution for high power applications," in Proc. IEEE 34th IAS Annu. Meet. Conf. Rec. Ind. Appl. Conf., Oct. 1999, vol. 3, pp. 1520-1527.

[32] A. Nami, F. Zare, A. Ghosh, and F. Blaabjerg, "A hybrid cascade converter topology with series-connected symmetrical and asymmetrical diodeclamped H-bridge cells," IEEE Trans. Power Electron., vol. 26, no. 1, pp. 51-65, Jan. 2011.

[33] A. Chen and X. He, "A hybrid clamped multilevel inverter topology with neutral point voltage balancing ability," in Proc. IEEE 35th Annu. Power Electron. Spec. Conf., Jun. 20-25, 2004, vol. 5, pp. 3952-3956.

[34] R. S. Kanchan, M. R. Baiju, K. K. Mohapatra, P. P. Ouseph, and K. Gopakumar, "Space vector PWM signal generation for multilevel inverters using only the sampled amplitudes of reference phase voltages," IEE Proc.-Electr. Power Appl., vol. 152, no. 2, pp. 3297-309, Apr. 2005.

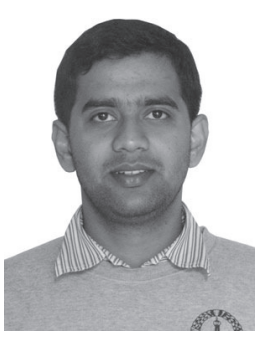

P. Roshankumar received the B.E. degree in electrical and electronics engineering from Acharya $\mathrm{Na}-$ garjuna University, Andhrya Pradesh, India, in 2006, and the M.Tech. degree in electronic design from the Centre for Electronics Design and Technology, Indian Institute of Science, Bangalore, India, in 2010, where he is currently working toward the Ph.D degree

His research interests include renewable energy systems, power electronics, and electro mechanic systems. 


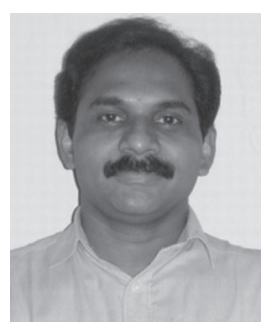

P. P. Rajeevan received the B.Tech. degree in electrical engineering from the University of Calicut, Kerala, India, and the M.E. degree in power electronics from Bangalore University, Bangalore, India. $\mathrm{He}$ is currently working toward the Ph.D. degree at the Centre for Electronics Design and Technology, Indian Institute of Science, Bangalore.

His research interests include multilevel power converters, drives, pulse-width modulation techniques, and power quality.

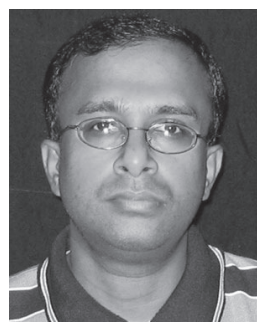

K. Mathew received the B.E. degree in electronics and communication engineering from Kurunji Venkatramana Gowda Engineering College, Mangalore, India in 1994, and the M.Tech. degree in electronic design from the Centre for Electronics Design and Technology, Indian Institute of Science, Bangalore, India, in 2006, where he is currently working toward the Ph.D. degree.

$\mathrm{He}$ is a Faculty Member in the Department of Electronics Engineering, Mar Athanasius College of Engineering, Kothamangalam, India. His research interests include embedded systems, power electronics, and electro mechanic systems.

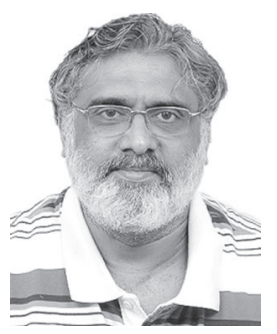

K. Gopakumar (M'94-SM'96-F'11) received the B.E., M.Sc. (Engg.), and Ph.D. degrees from the Indian Institute of Science, Bangalore, India, in 1980, 1984, and 1994, respectively.

He was with the Indian Space Research Organization, Bangalore, India from 1984 to 1987 . He currently holds the position of Chairman and Professor at the Center for Electronics Design and Technology, Indian Institute of Science. His research interests include pulse-width modulation converters and high power drives.

Dr. Gopakumar is a Fellow of Institution of Electrical and Telecommunication Engineers, India and Indian National Academy of Engineers. He is currently an Associate Editor of the IEEE TRANSACTION ON INDUSTRIAL ELECTRONICS.

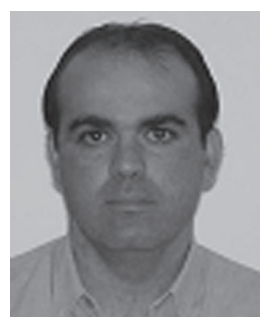

Jose I. Leon (S'04-M'07) was born in Cádiz, Spain, in 1976. He received the B.S., M.S., and Ph.D. degrees in telecommunications engineering from the University of Seville (US), Seville, Spain, in 1999, 2001 and 2006, respectively.

He is currently an Associate Professor with the Department of Electronic Engineering, US. His research interests include electronic power systems, modulation and control of power converters, and industrial drives.

Dr. Leon recieved the 2008 Best Paper Award of the IEEE Industrial Electronics Magazine as the coauthor.

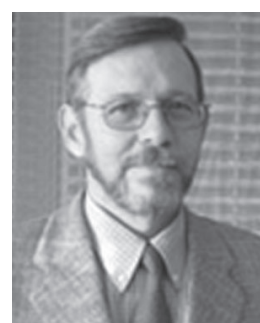

Leopoldo G. Franquelo (M'84-SM'96-F'05), received the M.Sc. and Ph.D. degrees in electrical engineering from the University of Seville, Seville, Spain, in 1977 and 1980, respectively.

He was the Head of the Electronics Engineering Department (1998-2005). He is currently a Full professor and the Head of the Power Electronics Group with the University of Seville. From 2002 to 2003, he was the Vice President of the Industrial Electronics Society (IES) Spanish Chapter and a Member at large of the IES Administrative Committee. He was the Vice President for conferences (2004-2007), in which he has also been a Distinguished Lecturer since 2006. He is the holder of ten patents and participated in $96 \mathrm{R} \& \mathrm{D}$ projects. He has been the president of IES (2010-2011). He is the author of more than 60 publications in international journals and 180 papers in international conference proceedings. His current research interests include modulation techniques for multilevel inverters and its application to power electronic systems for renewable energy systems.

Dr. Franquelo has been an Associate Editor of the IEEE TRANSACTIONS ON INDUSTRIAL ELECTRONICS since 2007. 